Ссылка: Бурденко Е.В. Эволючия взглядов ученых на роль и значение образования в развитии общества и человека//Наука и образование. Новые технологии. Межвузовский сборник научных трудов. - М.: ИИЦ МГУДТ. 2006. c.3-8

\title{
http://elibrary.ru/item.asp?id=24996074
}

\section{ЭВОЛЮЦИЯ ВЗГЛЯДОВ УЧЕНЫХ НА РОЛЬ И ЗНАЧЕНИЕ ОБРАЗОВАНИЯ В РАЗВИТИИ ОБЩЕСТВА И ЧЕЛОВЕКА}

Бурденко Елена Викторовна - почетный работник высшего профессионального образования, кандидат экономических наук, доцент кафедры политической экономии Российского экономического университета им. Г.В. Плеханова,

ResearcherID: E-3369-2014

orcid.org/0000-0001-5073-5062

burdenko-ev@yandex.ru

\begin{abstract}
Аннотация
В статье уделено внимание проблемам теоретического осмысления изменения уровня заработной платы и экономической эффективности работников, прошедших обучение. Социально-экономическую эффективность образования рассматривали в своих трудах следующие ученые: У. Петти, А. Смит, К. Маркс, А. Маршалл, Т. Шульц, Г. Беккер, Я. Минсер. И. Фишер, Л. Вальрас, и другие.
\end{abstract}

Ключевые слова: экономика образования, теория человеческого капитала.

\section{THE EVOLUTION OF SCIENTIFIC VIEWS ON THE ROLE AND IMPORTANCE OF EDUCATION IN DEVELOPMENT OF SOCIETY AND MAN}

Burdenko, Elena V. - honorary worker of higher professional education, $\mathrm{PhD}$, Assistant Professor of the Department for Political Economy of the Plekhanov Russian University of Economics,

ResearcherID: E-3369-2014

orcid.org/0000-0001-5073-5062

burdenko-ev@yandex.ru

Abstract

In the article attention is paid to the problems of theoretical interpretation of changes in wages and economic efficiency of employees trained. Socio-economic efficiency of education was considered in the works of the following scholars: W. Petty, A. Smith, K. Marx, A. Marshall, T. Schultz, G. Bekker, J. Minser, I. Fischer, L. Walras, and others.

Keywords: Economics of education, human capital theory. 


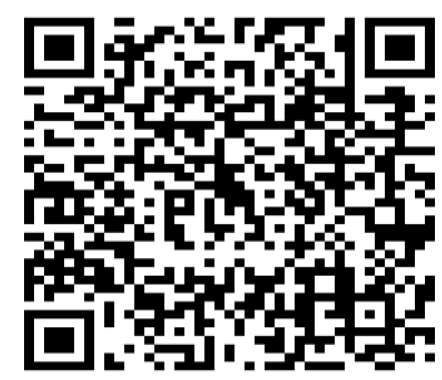

ЭВОЛЮЦИЯ ВЗГЛЯДОВ УЧЕНЫХ НА РОЛЬ И ЗНАЧЕНИЕ ОБРАЗОВАНИЯ В РАЗВИТИИ ОБЩЕСТВА И ЧЕЛОВЕКА

Бурденко Е.В. к.э.н.

\section{Российская экономическая академия им. Г.В. Плеханова}

Первая попытка обратить внимание на социально-экономическую эффективность образования принадлежит У. Петти, подсчитавшему ценность населения как составной части богатства королевства ${ }^{1}$. В дальнейшем А. Смит сравнивал человека, овладевшего той или иной профессией, с дорогостоящей машиной: «Предполагается, что после установления любой дорогостоящей машины, работа, производимая ею до момента наступления износа, окупит вложенный в неё капитал, принося прибыль по крайне мере обычного уровня. Человека, получившего образование ценой вложенных усилий и затраченного времени и овладевшего профессией, требующей выдающейся сноровки и навыков, можно сравнить с рассмотренной выше дорогостоящей машиной. Считается, что работа, которую он научился выполнять, будет оплачиваться выше заработной платы обычных сотрудников и позволит ему возместить все расходы на образование, принося при этом прибыль, которую, по крайней мере, приносит обычно равноценный капитал. Но это должно быть сделано в разумные сроки, так как продолжительность человеческой жизни неопределенна, так же как не определен срок службы машины. Разница между заработной платой

\footnotetext{
${ }^{1}$ Петти В. Экономические и статистические работы. М.: Соцэкгиз, 1940, - 324 с.

Петти В., Смит А., Рикардо Д., Кейнс Дж. М., Фридмен М. Классика экономической мысли. Соч. М.: ЭКСМО-Пресс, 2000.
} 
квалифицированного сотрудника и обычного сотрудника основана на этом принципе» ${ }^{2}$.

Вопрос о вкладе образования в повышение квалификации, в экономический рост и о влиянии его на величину доходов их обладателей классическая политэкономия решала в рамках трудовой теории стоимости. Задолго до К. Маркса А. Смит отмечал, что "один час занятия таким ремеслом, обучение которому потребовало 10 лет труда, может содержать в себе больше труда, чем работа в течение месяца в каком-нибудь обычном занятии, не требующем обучения".

Среди факторов, влияющих на дифференциацию заработной платы работников, А. Смит выделял легкость (и дешевизну) или трудность (и дороговизну) изучения данной профессии, а также степень доверия к работнику и меру его ответственности.

Ф. Лист характеризовал благосостояние нации не наличием богатства, а степенью развития созидающих его сил. Главной из этих сил он считал «умственный капитал», накапливаемый успехами в науках, искусстве, открытиями, изобретениями и т.п. А. Маршалл отмечал, что образование «служит важным средством увеличения производства материального богатства». Нельзя не согласиться с его мнением, что целесообразность затрат государства и частных лиц на образование не следует измерять только непосредственными практическими результатами. Такое размещение средств приносит и большие косвенные выгоды. «Образование позволяет многим, кто мог бы умереть в безвестности, получить возможность для раскрытия своих потенциальных способностей» ${ }^{3}$.

А. Маршал делает следующий вывод: «предложение труда данной квалификации при жизни настоящего поколения имеет тенденцию находиться в соответствии с заработками, которые приносила эта квалификация в предшествующем поколении». Именно А.Маршалл

\footnotetext{
${ }^{2}$ Смит А. Исследование о природе и причинах богатства народов. М.: Соцэкгиз, 1962

${ }^{3}$ Мильнер Б. Управление знаниями - вызов XX1 века.// Вопросы экономики, 1999
} 
сконцентрировал внимание на проблеме рынка образовательных услуг в связи с инвестированием в человеческий капитал. Ему принадлежит утверждение, что "самый ценный капитал - это тот, который вложен в человеческие существа".

Современная теория человеческого капитала отражает переориентацию экономической науки с проблем использования трудовых ресурсов на проблемы создания качественно новой рабочей силы в условиях постиндустриального общества, а применительно к развитию экономических систем - переориентацию с экономических показателей на социальные показатели. Ключевые идеи теории человеческого капитала были предвосхищены еще А. Смитом, но более стройное оформление и бурное развитие она получила в 60-е годы XX-го века в работах Т. Шульца, Г. Беккера, Я. Минсера.

Идеи, ставшие предтечей теории человеческого капитала, получили дальнейшее развитие в работах многих авторов, в частности И. Фишера. Вслед за Л. Вальрасом он определил капитал как любой запас (природные ресурсы, машины, сырье, трудовые навыки людей), который через какое-то время и в определенных условиях приносит поток услуг. Их превышение над затратами образует доход, реализуемый в виде процента. Заработная плата в таком контексте - по сути, процент на человеческий капитал, который может накапливаться точно так же, как капитал физический.

Большинство экономистов конца XIX века - начала XX века, таких как Ж.Б. Сэй, Н. Сениор, Дж. Милль, И. Фишер считали, что приобретенные человеком способности к труду следует рассматривать как капитал в его «человеческой» форме. При этом под человеческим капиталом понимают не только способность выполнять определенную работу, но и приобретенные знания и навыки человека, которые создаются путем инвестирования времени и труда в образование, влияющие на рост производства и дохода. Говоря о человеческом капитале, подразумевают - активы, обладающие такими признаками: 
- приобретенные навыки и способности являются результатом инвестиций;

- полученные навыки и способности приносят на протяжении определенного периода времени их владельцу поток дохода.

Сама идея заработной платы как процента на стоимость рабочей силы, рассматриваемой в качестве капитала, высказывалась задолго до И.Фишера и критиковалась еще в "Капитале". "К сожалению, - писал К.Маркс, - имеются два обстоятельства, неприятным образом опрокидывающих это безмозглое представление: во-первых, рабочий должен работать, чтобы получать эти проценты, и, во-вторых, он не может обратить в звонкую монету капитальную стоимость своей рабочей силы путем ее передачи другому". К.Маркс замечает, что подобные представления использовались не только вульгарными экономистами, но и немецкими статистиками, а еще раньше У. Петти.

Инвестируя в человеческий капитал, люди откладывают текущий доход с целью увеличить будущий. Инвестиции в человеческий капитал со временем должны окупиться, давая отдачу в виде высокой заработной платы или способности выполнять работу, приносящую большее удовлетворение.

Проблема каждого человека - максимизация своей полезности в течение всей жизни путем связанных с инвестициями в человеческий капитал затрат и доходов. Затраты и доходы могут принимать различные формы, как прямые денежные формы, включая предвидящиеся возможности, так и принимать форму нефинансовых затрат или выгод.

Человеку, принимающему решение о получении высшего образования после среднего образования, необходимо сравнить стоимость и выгодность продолжения обучения. Затраты могут быть как прямые, так и косвенные. Прямые затраты включают плату за обучение, стоимость книг и оборудования, а также любые дополнительные затраты на проживание, связанные с возможностью переезда в другой город. Косвенные затраты включают самую большую стоимость дальнейшего образования: 
предполагаемые доходы от занятости в то время, когда человек занят обучением (неполученный доход). Сюда могут входить и другие нефинансовые затраты, например отделение от семьи и друзей.

Большинство людей признают, что выгоды неденежного характера превышают аналогичные издержки. Люди принимают решения о вложениях в свое образование и профессиональную подготовку на основе сопоставления связанных с этим затрат и выгод. Но выгоды и затраты «принадлежат» к разным временным периодам. Приведение к настоящему моменту времени (дисконтирование) будущих выгод и затрат является ключевым аспектом. Рациональный вкладчик в человеческий капитал будет инвестировать средства до достижения такого уровня образования (подготовки), при котором предельные выгоды от образования будут покрывать предельные затраты. Достижение равновесия наступает в момент, когда норма отдачи от последней порции инвестиций в образование равна норме отдачи на другие виды вложений. Конечно, существует разница между человеческим и физическим капиталом:

1. Права собственности на человеческий капитал, т.е. на приобретенные навыки и способности работника, не могут быть переданы другому лицу.

2. Затраты на образовательные услуги, связаны с получением более высоких способностей, являются одним из важнейших благ для человека.

3. Величину и изменения человеческого капитала невозможно измерить с той же точностью, что и для оборудования.

Таким образом, инвестиции в человеческий капитал будут поощряться низкими затратами на образовательные услуги, а также высокими ожидаемыми дополнительными доходами за счет полученного образования и продолжительной трудовой жизнью.

Несмотря на имеющиеся затраты, которые несет человек, решивший продолжать обучение в вузе, он должен взвесить и все потенциальные выгоды от получения образовательной услуги. Например, более образованные люди получают более высокие доходы, чем менее 
образованные. Существуют и нефинансовые выгоды от инвестиций в образовательные услуги: высшее образование позволяет расширить выбор профессий и создать возможности для более подходящей занятости. Выгоды от образовательных услуг и полученных знаний получает и сам человек, в результате собственного развития, и предприятия, использующие труд образованного и профессионально подготовленного работника, да и экономика государства в целом.

\section{Список литературы}

1. Петти У. Экономические и статистические работы. М.: Соцэкгиз, 1940, $-324 \mathrm{c}$.

2. Петти У., Смит А., Рикардо Д., Кейнс Дж. М., Фридмен М. Классика экономической мысли. Соч. М.: ЭКСМО-Пресс, 2000.

3. Смит А. Исследование о природе и причинах богатства народов. М.: Соцэкгиз, 1962.

4. Мильнер Б. Управление знаниями - вызов XX1 века.// Вопросы экономики, 1999.

5. Бурденко Е.В. Рынок образовательных услуг в трансформируемой экономике: диссертация на соискание ученой степени кандидата экономических наук. М.: РЭА им. Г.В. Плеханова. 2004 г. 